University of Zurich

Department of Economics

Working Paper Series

ISSN 1664-7041 (print)

ISSN1664-705X(online)

Working Paper No. 1

\title{
What Determines the World Heritage List? An Econometric Analysis
}

Bruno S. Frey, Paolo Pamini and Lasse Steiner

January 2011 


\title{
WHAT DETERMINES THE WORLD HERITAGE LIST? \\ AN ECONOMETRIC ANALYSIS
}

\author{
by \\ Bruno S. Frey* \\ University of Warwick, \\ University of Zurich \\ and
}

CREMA - Center for Research in Economics, Management and the Arts, Switzerland

\author{
Paolo Pamini** \\ ETH Zurich
}

and

Lasse Steiner***

University of Zurich

(this version 22 Nov 2010/BSF)

\begin{abstract}
The official intention of the UNESCO World Heritage List is to protect the global heritage. However, the existing List is highly imbalanced according to countries and continents. Historical reasons, such as historical GDP, population, and number of years of high civilization, have a significant impact on being included on the List. In addition, economic and political factors unrelated to the value of heritage, such as rent seeking by bureaucrats and politicians, the size of the tourist sector, the importance of media, the degree of federalism, and membership in the UN Security Council, influence the composition of the List. (98 Words)
\end{abstract}

JEL Classification: Z11, F5, H87

Keywords: global public goods, world heritage, international organizations, international political economy, culture

\footnotetext{
* Distinguished Professor, Warwick Business School, University of Warwick, and Professor of Economics, Department of Economics, University of Zurich, Wilfriedstr. 6, CH-8032 Zurich, Switzerland. He is also Research Director of CREMA - Center for Research in Economics, Management and the Arts, Switzerland. Email: bsfrey@iew.uzh.ch

${ }^{* *}$ Lic. oec. publ., Chair for Intellectual Property, ETH Zurich, Raemistrasse 101, CH-8092 Zurich

*** Dipl. oec. publ., Institute for Empirical Research in Economics, University of Zurich Wilfriedstr. 6, CH-8032

Zurich, Switzerland.
} 


\section{THE WORLD HERITAGE LIST}

\section{A. The UNESCO Convention}

The World Heritage List compiled by UNESCO has become highly popular. Many regard it as "the most effective international legal instrument for the protection of the cultural and natural heritage” (Strasser 2002, 215). Most World Heritage Sites are major attractions for cultural tourism and are also icons of national identity (Shackley 2006, 85).

In the 1920s, the League of Nations became aware of the growing threat to the cultural and natural heritage of our planet. However, nothing concrete emerged despite years of intensive discussions and drafting of reports. In 1959, UNESCO launched a spectacular and successful international campaign to save the Abu Simbel temples in the Nile Valley. In 1966, UNESCO also spearheaded an international campaign to save Venice after disastrous floods threatened the survival of the city. At its 17th session in Paris in November 1972, the General Conference of UNESCO adopted the Convention concerning the Protection of the World Cultural and Natural heritage (UNESCO 1972). The Convention (Art. 4) recognizes "the duty of ensuring the identification, protection, conservation, presentation and transmission to future generations of the cultural and natural heritage” around the world considered to be of outstanding value to humanity. It came into force in 1977 with 20 nations ratifying it. The Convention now includes 187 countries (UNESCO 2010), and the World Heritage List comprises 940 Sites, ${ }^{1} 721$ (or 77 percent) of which relate to culture, 192 to nature, and 27 are mixed; that is, they combine cultural and natural heritage.

The advisory bodies to the World Heritage Committee evaluated in a somewhat ad hoc fashion the sites initially included on the List. The Convention's criterion of outstanding value to humanity is noble but proved to be almost impossible to define clearly. Therefore, an important development was the establishment of 10 criteria for inclusion in the World Heritage List, which are covered in detail in the Operational Guidelines for the Implementation of the World Heritage Convention (UNESCO 2005a). Nominated sites must meet at least one of the 10 criteria (UNESCO 2005b), which take into account three comprehensive aspects: uniqueness, historical authenticity, and integrity or intactness. Six criteria refer to Cultural and four to Natural Sites. The former must "represent a masterpiece

\footnotetext{
${ }^{1}$ After the 34th ordinary session of the World Heritage Committee, held in Brasília on July 25-August 3, 2010, the World Heritage List contains 911 Sites. For our purposes, we count Sites extending over more than one country as many times as the number of countries involved, therefore obtaining a higher number of Sites. We also disregard the two delisted Sites.
} 
of human creative genius” (criterion i). The latter should “contain superlative natural phenomena or areas of exceptional natural beauty and aesthetic importance” (criterion vii). Appendix I of the Operational Guidelines contains the full list of criteria, as does our Appendix.

The composition of the World Heritage List is the outcome of actions by three different bodies: the state parties that nominate the Sites, the committee that formally decides inclusion on the List, and two advisory boards. These bodies evaluate and propose the Sites for inscription. Member governments must propose the sites to be included on the List. Mayors, district governments, or heritage experts may only make proposals for inclusion on a tentative list. The official nomination of a Site occurs when a country hands in a complete nomination document.

The World Heritage Committee meets once a year and consists of representatives from 21 of the member countries. The General Assembly of the members of the Convention elects this committee for terms of up to six years. The intention of the Convention is an equitable representation of the world's regions and cultures (Art. 8 [2]). However, the Convention nowhere mentions the means to achieve this goal. The Committee is the final decision-making body whose responsibilities include the World Heritage List, the List of World Heritage in Danger, administering the World Heritage Fund, and decisions on financial assistance. The World Heritage Convention is different from many other international conventions because all substantive powers are designated to the Committee and not to the General Assembly. The Committee is advised by the International Council on Museums and Sites (ICOMOS) for Cultural sites, by the International Union for Conservation of Nature (IUCN) for Natural sites, and by the International Centre for the Study of the Preservation and Restoration of Cultural Property (ICCROM). It has been claimed: "The scrutiny of these systems by the two Advisory Boards is now rigorous...." (Cleere 2006, xxii).

\section{B. Literature}

There is an extensive literature on World Heritage and the UNESCO program; recent contributions are, for example, Leask and Fyall (2006), Harrison and Hitchcock (2005), van der Aa (2005), Leask and Yeoman (2004), and Howard (2003). The following aspects have received special attention: the process of designation with respect to its formal nature; the stakeholder groups participating as well as their politics (e.g., Strasser 2002; Millar 2006; 
Cleere 2006); the consequences of inclusion in the World Heritage List, especially with respect to tourism (e.g., Tunney 2005; Cochrane and Tapper 2006 ); visitor management (e.g., Shackley 2006; McKercher and du Cros 2001); as well as case studies of individual Sites (e.g., for Stonehenge, Mason and Kuo 2006; for Machu Picchu, Regalado-Pezúa and Arias-Valencia 2006; for the Yellow Mountain in China, Li Fung and Sofield 2006; or for Angkor, Wager 1995).

In economics, few works deal with UNESCO’s World Heritage: the doctoral dissertation by van der Aa (2005), the book by Santagata, de Caro, and Marrelli (2008), and the articles by Frey and Pamini (2009, 2010) and Frey and Steiner (2010) being exceptions. An excellent analysis of general heritage issues is provided in Peacock and Rizzo (2008). Other economic analyses mainly evaluate the utility of preserving the past as well as financial consequences (see, e.g., Benhamou 1996, 2003; Frey 1997; Greffe 1999; Klamer and Throsby 2000; Mossetto 1994; Mossetto and Vecco 2001; Netzer 1998; Peacock 1978, 1995; Rizzo 2006; Streeten 2006; Throsby 1997a, 1997b, 2003). The collection of articles in Hutter and Rizzo (1997), Peacock (1998), and Rizzo and Towse (2002) also contain references to heritage, as do the more general monographs and collections by Frey (2003), Ginsburgh (2004), Ginsburgh and Throsby (2006), Towse (1997, 2003, 2010), and Throsby (2001, 2010). The consequences of being listed, in particular on the number of visitors frequenting these Sites, are studied, for example, in Bonet (2003), Tisdell and Wilson (2002), and Yang, Lin, and Han (2009).

\section{Procedure}

The effort of UNESCO to establish a World Heritage List containing the most treasured Sites of humanity's culture and landscapes constitutes a great step forward towards preserving one of the most important global public goods on our planet. However, the List also has negative aspects that are often overlooked (see Section II). One striking aspect is the highly unequal distribution of Sites across countries and continents, which suggests that other factors than the 10 UNESCO “objective” criteria play a role (see Section III). In order to determine these factors, we first empirically investigate possible historical, cultural, or natural reasons why some countries have more sites than others do. The number of years a country has been a member of the Convention, the size of a country, the number of years that it has been part of a civilized culture, as well as historical GDP and population size are positively and significantly correlated with the number of Sites a country exhibits today (see Section 
IV). Using these historical factors as controls, we estimate cross-section and panel-data models to identify the stock and flow determinants of getting on the List. The impact of the relative importance of the tourist sector (negative), the media sector, federalism, and being a member of the UN Security Council (positive) on the number of Sites a country obtains are the most robust (see Sections V and VI). Section VII concludes that factors unrelated to the value of heritage have a significant impact on the composition of the List.

\section{POSITIVE AND NEGATIVE ASPECTS}

The World Heritage List is generally considered an excellent contribution to saving the globe's common history in the form of cultural monuments and landscapes worth preserving. The undisputed and well-known positive effects of being on the List relate mainly to the attention attracted and improved protection. Being on the List attracts the attention of the general public, public decision makers, potential donors, and for-profit firms. As long as this additional attention leads to increased funding, it is beneficial for maintaining the Sites. To support the preservation of Sites, UNESCO offers technical but only very limited financial help. ${ }^{2}$

Being on the List is also related to some negative aspects (for an extensive discussion of the benefits and negative aspects of the World Heritage List, see Frey and Steiner 2010). First, the prominence of the List can contribute to the destruction of a Site. A higher number of visitors can accelerate deterioration. For example, this has been the case for Machu Picchu and the Heart of Neolithic Orkney, where access to parts of the Site has had to be restricted due to condensation problems. The Sites can also become a target in times of war (such as the bridges in Mostar, the city of Sarajewo, or the mosques in Banja Luka) or a target for terrorists. Second, an undesired substitution effect may take place when politicians, bureaucrats, and firms reallocate funds from other sites to those on the List. The loss of funds of the non-UNESCO sites may well lead to the overall heritage being less well preserved. Third, the number of Sites on the UNESCO List has continuously grown (at an accelerating rate) over time. The Convention does not set a numerical limit for the List, and this overextension of the List imposes problems whereby the Committee has to monitor the state of conservation and management of the Sites.

Fourth, and most important here, the selection of the Sites is questionable because it is subject to rent seeking by experts and politicians. That is, politicians in their respective

\footnotetext{
${ }^{2}$ The corresponding fund is only $\$ 4$ million per year for over 900 Sites listed.
} 
countries and expert representatives on the advisory groups ICOMOS and IUCN strongly influence the selection of what Cultural and Natural Sites should be on the List. In most cases, the Committee follows the experts' recommendations. As a result, the definition of what is "outstanding universal value" is transferred from the Committee to a political body or technical experts. (Pressouyre 1996). Technical experts rely on their knowledge as art historians and conservators, but "the concept ... has never been the object of a truly operational definition” (Musitelli 2002, 329).

Some scholars even question the legitimacy of the List. Meskell (2002) argues that the concept of World Heritage is flawed by the fact that it privileges an idea originating in the West, which requires an attitude toward material culture that is distinctly European in origin. Affluent countries seem to have benefited most from the Convention. According to a Report of the World Commission on Culture and Development, the World Heritage List "was conceived, supported and nurtured by the industrially developed societies, reflecting concern for a type of heritage that was highly valued in those countries” (Olmland 1997). Moreover, many countries do not have the necessary conservation infrastructure that allows them to prepare nominations to the List at a sufficiently sustained pace to improve its representativity (Strasser 2002, 226-227). According to the Convention, the state parties must identify and delineate the property (Art. 3); in addition, they must ensure the identification, protection, conservation, presentation, and transmission to future generations (Art. 4). These requirements put a heavy burden on countries wishing to put a site on the List.

Being on the UNESCO List is highly desired by many as it brings prominence and monetary revenue; one may even speak of a "heritage industry" (Johnson and Thomas 1995). As a consequence, the process of getting on the List is subject to rent seeking (Buchanan 1980; Tollison 1982). It has been highly politicized as many political and bureaucratic representatives of countries consider it a worthwhile goal from which they personally profit. Consequently, the selection is subject to political pressures; thus, it is not determined solely by the 10 criteria listed above deemed to be “objective.” Although the goal of the whole project is to protect Sites of central importance for humanity, as expected, national interests dominate global interest. "The rhetoric is global: the practice is national." (Ashworth and van der Aa 2006, 148.) Some countries more actively try to secure Sites to be included on the List. Twenty-one nations participating in the Convention have a seat on the World Heritage Committee. However, these members nominated more than 30 percent of the listed Sites between 1978 and 2004 (van der Aa 2005, 81). One example of a questionable selection occurred in 1997 when 10 Italian Sites where included on the List all at once, whereas the 
chair of the Committee was a compatriot at that time. Also, the location within the country where the Committee holds its annual meeting seems to have an impact on the number and kind of nominations (for example, the meeting in 1997 that was just mentioned was held in Naples, see Cleere 1998). Francesco Bandarin, the Director of the World Heritage Centre, acknowledges, "Inscription has become a political issue. It is about prestige, publicity and economic development” (Henley 2001).

\section{UNEQUAL DISTRIBUTION OF SITES}

A striking aspect about the UNESCO List is the highly unequal distribution of Sites among continents. Forty-six percent of the Sites are in Europe. ${ }^{3}$ The European predominance is larger for Cultural Sites (53 percent) than for Natural Sites (23 percent). In contrast, subSaharan Africa has less than 9 percent of all Sites, and the Arabian countries have 7 percent. The Americas and Asia-Pacific are represented better with 17 percent and 21 percent, respectively (see Table 1 ).

\section{TABLE 1}

If the distribution according to the population is taken as a reference, Europe is still on top with 52 Sites per 100 million persons followed by the Arabian countries, the Americas, and sub-Saharan Africa with 23, 18, and 11 Sites per 100 million people, respectively. AsiaPacific has much less with five per 100 million people. Europe also leads the distribution of sites per square kilometer with 19 Sites per million square kilometers, whereas all other continents possess between four and five.

The distribution of Sites across countries is also highly skewed. Some countries in the world have a large number of World Heritage Sites; whereas, other countries have few, and a considerable number have none (see Tables 2 and 3).

\section{TABLE 2, TABLE 3}

It could be argued that every country should have the same importance with respect to its contribution to the heritage of humankind. This point of view emphasizes that every country should be of equal worth with respect to its culture for an international organization

\footnotetext{
${ }^{3}$ Continents follow the UN definition.
} 
such as the UN and its agency UNESCO. This applies not only to "culture” in the broadest sense but also to "nature”: each country has Cultural and Natural Sites worth preserving. With an equal number of Sites per country, any attempt to compare the "value" of the Sites among countries would be futile. Clearly, this is an extreme position because it does not take into account the size of a country as measured by population or geography (for detailed information about the distribution of Sites, see Frey and Pamini 2010).

The imbalance of World Heritage Sites according to continents and countries has been present from the beginning, and it has become a subject of major concern within the World Heritage Commission and Centre, UNESCO, and beyond. The Director of the World Heritage Centre, Francesco Bandarin, even went so far as to call the World Heritage List “a catastrophic success” (Henley 2001). As a reaction to this imbalance, in 1994, the World Heritage Committee started the Global Strategy for a Balanced, Representative and Credible World Heritage List, which intends to raise the share of non-European Sites as well as the share of living cultures, especially "traditional cultures" included on the List. Despite this explicit policy and intended strong action, "the immediate success of these efforts is questionable” (Strasser 2002, 226). European countries make the best use of the opportunities offered by the "global strategy." Regardless of whether one looks at cultural landscapes, modern Twentieth Century heritage, industrial heritage, or prehistoric heritage, Europe benefits the most from the opportunity to nominate sites in these categories, which are emphasized by the global strategy.

An unequal distribution of Sites of course does not necessarily mean that the selection is biased. However, a strongly unequal selection suggests that inappropriate aspects may play a role, such as political or bureaucratic rent seeking among the member countries. These aspects are unrelated to the value of global heritage. In the remainder of this paper, we present empirical results of the factors determining the number of Sites on the List by country.

\section{HISTORICAL DETERMINANTS}

In a first step, we investigate factors based on history, which might explain why some countries deserve more Sites on the List than others do. The influence of these historical determinants can be estimated by cross-section regressions because the variables do not change over time. 
Cultural and Natural Sites differ in their characteristics; therefore, different UNESCO criteria are applied. Consequently, separate regressions are used with either the total number of Cultural or Natural Sites per country in 2006 as a dependent variable (since most of the independent variables in the following regressions only existed until 2006). Appropriate techniques to explain a dependent variable that only takes natural numbers are a Poisson regression for count or negative binomial regressions. Table 4 presents the estimated coefficients of a negative binomial regression in order to cope with the so-called overdispersion of the data, that is, a variance greater than the expected value, which the Poisson model is not able to take into account. ${ }^{4}$

\section{TABLE 4}

As a technical control variable, we use the number of years of a country in the World Heritage Convention, since a Site can only be listed if the respective country is a member of the Convention. As expected, the coefficient is positive in all specifications, that is, a country that has belonged to the Convention longer has more sites on the List. In most regressions, this coefficient is highly significant. The coefficients vary around 0.06 (eq. 3). The size of the coefficients can be interpreted by exponentiating the estimated coefficient to get the so-called incidence rate ratio (IRR); that is, the factor change in the expected count of Sites for a unit increase in the independent variable. In estimate (3), tenure has, for instance, an IRR $=\mathrm{e}^{0.059}=$ 1.0689, which means that an increase in Convention membership by one year (i.e., one unit in our scale) leads to a relative increase of the expected number of Cultural Sites of IRR $-1=$ 6.89 percent.

With regard to the size of a country, one expects that the larger a country the more likely it is to find Sites worth including in the List. This argument seems to be more convincing for Natural than for Cultural Sites. A large country is expected to have more different types of landscapes that fit the UNESCO criteria. The estimations of the impact of country size (area in million square kilometers) support this hypothesis. The coefficient for Natural Sites is always positive and significant, and it is larger than the one for Cultural Sites. For example, the coefficient of 0.141 in equation (1) indicates that an increase in a country's

\footnotetext{
${ }^{4}$ For count data with many zeros, one can also estimate zero-inflated negative binomial regression models. In our case, these models lead to qualitatively and quantitatively very similar results. In Stata, count data models can be compared with the "countfit" command. A comparison of the residuals, the sum of the Pearson statistic, and the AIC and BIC statistics suggest applying negative binomial regressions to our data. Thus, we only show the results of these estimations.
} 
size of one million square kilometers leads to a relative increase of the expected number of Cultural Sites of 15.2 percent.

As mentioned above, the distribution across continents is highly unequal. The multiple regression results are consistent with the descriptive statistic. When compared to Europe, all other continents have significantly fewer Cultural Sites, even when controlling for tenure and size of the country. For Natural Sites, the result is different. When compared to Europe, the Arabian countries have significantly fewer, whereas the Asian and Pacific countries have significantly more Natural Sites.

Although the continent dummies can account to some extent for cultural and historical differences, variables on a country level are more precise. We use O’Brien’s (2002) overview of the great cultures of the world to account for a country's history. ${ }^{5}$ The variable "years of high civilization" reflects the number of years a country has been a part of one of the 16 most important historical cultures. One can expect that the more years a country experienced such high civilization, the more Cultural Sites that it contains. The regression results are consistent with this hypothesis: The coefficient for Cultural Sites is positive and highly significant. The coefficient for Natural Sites in contrast is, as expected, statistically not significant, which supports our analysis. The coefficient of 0.000543 in equation (3) indicates that an increase in the period of high civilizations by 100 years leads to a relative increase of the expected number of Cultural Sites of 5.44 percent.

To verify the impact of the historical development of a country on the number of Sites on the List, we use the historical GDP per capita and population data as used in Maddison (2007). The range of the data is from year 1 to 2008 (year 1, 1000, 1500, 1600, 1700, 1820, and yearly thereafter). However, in earlier years there are many missing values. We selected two points in time (1500 and 1820) with comparatively few missing values but with a substantial amount of time in between to cover different periods. These points in time seemed to be especially appropriate for Cultural Sites since the majority of Cultural Sites stem from the period between the tenth and the eighteenth century (van der Aa 2005). We use historical GDP per capita to investigate the impact of the development of a certain country at a given point in time. Despite many missing values, the estimated coefficients for GDP per capita on the number of Cultural Sites are significant and positive. As expected, the historical GDP per capita has no significant impact on the number of Natural Sites.

\footnotetext{
${ }^{5}$ These are Mesopotamian, Arabian, Phoenician, Persian, Egyptian, Ottoman, Jewish, Greek, Occident, Aegean, Roman, Byzantine, Indian, Chinese, Mongolian, and Japanese.
} 
Considering the role of the size of population, we test the hypothesis to see whether the historical population size has a positive impact on the number of Cultural Sites. Hereby we implicitly assume that each person of the world has the same capacity to create cultural goods. The coefficients of the historical population size are in line with expectations: The larger the historical population was in 1500 and 1820, respectively, the higher the number of Cultural Sites in one country. As expected, the historical size of the population has no significant effect on the number of Natural Sites. Because the historical data exhibit many missing values, we continue by using tenure, area, and civilization years as controls in further estimations.

\section{CROSS-SECTION ESTIMATIONS: STOCK DETERMINANTS}

Being on the UNESCO List is desired by many because it brings prominence and monetary revenue, especially from increased tourism. Therefore, the process of getting on the List is subject to rent seeking and has been highly politicized. The selection is subject to political pressures and is not solely determined by the 10 criteria deemed to be "objective" according to the Convention. Some countries are more active than others to secure Sites to be included in the List (van der Aa 2005, 81).

The politicians in a country decide whether they want to nominate a Site for the List. In a second step, experts provide advice to the World Heritage Committee, which makes the final decision about new Sites (for an extensive discussion of the process, see, e.g., Strasser 2002). Several factors determine the rent-seeking process within a country and on an international level (e.g., within international organizations, such as UNESCO). Possible rentseeking factors within a country are the size of the tourist sector, the distribution of information via media, economic development, democratic institutions, bureaucracy, and federalism. Determinants that influence the nomination on the international level are the power of a country as expressed by GDP or the size of the population, openness, and influence in international organizations. The separation between these two dimensions is not always clear-cut; we prefer to order the variables as economic (GDP, GDP per capita, tourist sector, globalization) and political determinants (size of population, media, democracy, bureaucracy, federalism, and membership on the UN Security Council).

Rent seeking can be expected to have the same influence with respect to Cultural and Natural Sites if it provides the same prestige and the criteria allow the same extent of manipulation. In this respect, the distinction between Natural and Cultural Sites is somewhat 
artificial (Pressouyre 1996). Consequently, the following regressions use the total number of Sites in 2006 as a dependent variable. First, we test the impact of the economic variables, always controlling for tenure, area, and years of civilization. Various economic determinants are introduced in sequence and then simultaneously tested (see Table 5).

\section{TABLE 5}

Total GDP is positively and significantly correlated with the number of total Sites. Economically powerful countries that tend to have higher weight with UNESCO and other international organizations are able to put more Sites on the List.

The GDP per capita (GDPPC) is positively and significantly related to the number of total Sites. Economically more developed countries have more Sites. They may have a larger number of Sites for historical reasons and/or they may be better able to lobby for inclusion on the List. This also involves being able to prepare the documentation necessary for a successful application (see Strasser 2002). An argument in favor of this correlation is that more developed countries may be better able to maintain their Sites.

The total number of tourists has a positive and significant impact. However, if accounting for the size of the population by taking the share of tourists divided by the total population, the impact becomes statistically insignificant. If using the relative importance of the tourist sector, namely the expenditures of tourists as a share of exports, the impact is statistically significant and negative. ${ }^{6}$ Politicians and bureaucrats in a country with a low tourist income have higher incentives to lobby for more Sites on the List. In contrast, countries with an already well-developed tourist sector are less dependent on the World Heritage List to promote tourism. With respect to tourism, the cross-country estimation obviously raises the question of reverse causality because it is well-known that after a Site is nominated tourist numbers increase significantly. However, one single Site only accounts for a very small part of a country’s tourism. We further address this issue in our panel estimations in Section VI.

The openness of a country, represented by the KOF index of globalization (Dreher 2006) comprises economic, social, and political globalization. The coefficient is positive and statistically significant: The more a country interacts with other countries the larger the number of Sites. This may be due to a higher international reputation of such countries or

\footnotetext{
${ }^{6}$ This variable is sometimes also used as measure for tourist specialization. See Arezki, Cherif, and Piotrowski (2009).
} 
because politicians in these countries care more about international recognition as offered by the UNESCO label, and therefore they engage more in UNESCO activities.

Testing all relevant economic factors simultaneously (eq. 19), the results hold: GDP and globalization are positively and significantly related to the number of Sites on the List, and tourist expenditures are negatively and significantly related. The coefficient of GDP per capita however is no longer significant. Therefore, we omit the variable in further regressions in order not to lose observations and because of a high correlation with the variables for globalization and media.

The first political determinant refers to a country's power measured by the size of today's population (Table 6, eq. 20). When using control variables, the population size shows no impact on the number of Sites. It can be concluded that the size of a country's area is the more important determinant.

\section{TABLE 6}

The role of the media is an important political and economic factor. It is expected that countries with a higher median density will have a higher number of Sites on the List. When more people are informed about (possible) Sites on the List, politicians and bureaucrats have a higher incentive to engage in the process in order to achieve recognition and profit from the popularity of the List. Possible media channels through which people are informed include newspapers, radio, TV, and the Internet. These variables are highly correlated with each other, but the number of Internet users has the fewest missing values. The number of Internet users is positively related to the number of Sites on the List in a statistically significant way. The more people have access to the news, the higher the incentive for politicians to lobby for putting national Sites on the List.

The extent to which a country is democratic or autocratic also can influence the rentseeking efforts of politicians. We expect that the more democratic a country is the more Sites it will have on the List because politicians in these countries depend more strongly on the need to be reelected. We use the Polity IV Index for Political Regime Characteristics and Transitions, which codes democratic characteristics (Polity 2010). The estimated coefficient is indeed positive and statistically significant: Countries with more democratic institutions have a higher number of Sites on the List.

The general importance of a government (and bureaucracy) in a country can be captured by the share of government spending in GDP. The higher the public expenditure 
share is, the bigger the influence of politicians and the size of bureaucracy in a country is. A higher share is expected to be correlated with a higher degree of rent seeking, but it also means better possibilities to prepare the applications for the List. The estimated coefficient turns out to be positive and statistically significant.

Countries with higher degrees of federalism are expected to have a higher number of Sites on the List. In more federal countries, a larger number of politicians want to profit from the popularity of the List. The sites to be included in the List must be proposed by member governments. However, mayors, district governments, or heritage experts make proposals for inclusion on the tentative list. A measure for federalism is included in the index published by the Database of Political Institutions (Beck et al. 2001). It should be noted that by using this index more than 50 percent of the observations are lost. The estimated coefficient is positive and significant: A more decentralized country has more Sites on the List, consistent with the theoretical hypothesis.

The influence of international organizations, especially organizations of the UN, is expected to be reflected in a larger number of Sites on the UNESCO List. Dreher, Sturm, and Vreeland (2009) show that being a member of the UN Security Council is related with receiving favorable treatment from the World Bank and IMF. To test the effect of membership in other important organizations, we count the years a country has been a permanent or nonpermanent member of the UN Security Council since it became a member of the World Heritage Convention. Interestingly, countries that have been a permanent or nonpermanent member for a longer period of time have a significantly higher probability of having a larger number of Sites on the List.

Controlling for the political determinants simultaneously (eq. 26 and 27), the main results are unaffected: Media (measured by Internet users), federalism, and UN Security Council membership (permanent and rotating) are significantly and positively correlated with the number of Sites. The Polity IV Index for democratic institutions is still positive but statistically insignificant (when controlling for federalism, which produces many missing values, see eq. 27), whereas the size of government spending becomes statistically insignificant.

In a last step, we estimate the economic and political determinants simultaneously (see Table 7). ${ }^{7}$ The main results hold (including statistical significance): Relative tourist

\footnotetext{
${ }^{7}$ GDP, tourist expenditures, media, UN Security Council, and federalism. The globalization index is omitted to prevent problems of collinearity because it is highly correlated with the variable for media use. Further, we omit
} 
expenditures are negatively correlated with the number of Sites; the coefficients of the number of Internet users (as a proxy for the influence of media in general), membership in the UN Security-Council, and federalism are positively related. ${ }^{8}$

\section{TABLE 7}

Interestingly, when membership on the UN Security Council is included among the determinants, the economic power of a country becomes insignificant. This suggests that the power of a country does not take effect through its sheer size or economic power but through its influence in international bodies.

We are fully aware that cross-section regressions cannot rule out reverse causality. However, for most determinants, reverse causality seems to be highly implausible. The number of Sites is unlikely to influence country size, years of past civilizations, membership on the UN Security Council, or the degree of federalism. The only variable where reverse causality seems to be an issue in a cross-section setting is tourism. It is known that the number of tourists for a Site or region increases after a Site is listed (e.g., Yang, Lin, and Han 2009). Two aspects might mitigate this problem in a cross-section setting. First, the impact of one Site on a country's total tourist numbers or expenditure is very small. Second, substitution effects within a country (sites not listed lose tourists) make the effect on total tourist numbers ambiguous (Arezki, Cherif, and Piotrowski 2009). In the panel estimations, we address this problem again.

\section{PANEL ESTIMATIONS: THE DETERMINANTS OF NEWLY ADDED SITES}

The panel structure of our data set allows us to estimate the flow determinants of the Sites added yearly on the World Heritage List. The data range from 1972 to 2006, and the number of Sites nominated in a given year serves as a dependent variable. The number of Sites again can be distinguished into total Sites, Cultural Sites, and Natural Sites. We cannot estimate fixed-effect models because some of the variables do not vary over time. Among these is not only size of the area but also the historical GDP and population data.

GDP per capita and the size of the population not to lose more observations and for reasons of collinearity with media, respective area, and GDP.

${ }^{8}$ In regression (29), tests have shown that area and tourist expenditures become insignificant because of too many missing values not because of the impact or correlation with federalism. When running regression (28) with the same observations ( $\mathrm{N}=64)$, the coefficients of area and tourist expenditure are insignificant, which indicates that in regression (29) they become insignificant due to too few observations. 
Table 8 depicts the negative binomial panel regressions results with random effects for the historical determinants. The Likelihood-ratio test indicates that the panel structure is preferred over a pooled estimation.

\section{TABLE 8}

The results from the cross-section estimations hold: The impact of the size of the country is again positive, significant, and bigger for Natural Sites. Years of civilization, historical GDP, and historical population only have an impact on the number of Cultural Sites a country gets in a given year not on the number of Natural Sites. However, there is an interesting difference to the stock estimations concerning the impact of tenure: The number of years a country has been part of the Convention is negatively correlated with the number of Sites a country gets in a given year. The cross-section estimation suggests that the more years a country has been a member of the Convention the more sites it had in 2006. The panel estimation results show a decreasing marginal rate of new Sites. There may be two reasons for this: First, a country with longer tenure already has more Sites, so its stock of potential Sites is lower. Second, with longer tenure, there is increased competition among countries (more countries joined the Convention), so the probability of getting a new Site in a given year decreases.

To estimate the influence of the economic and political determinants, we perform negative binomial regressions with random effects and pooled cross-section structure (Table 9). The pooled estimates contain year and continent fixed effects as well as interaction effects of year and continent. The estimations of the economic and political determinants are well in line with the cross-section results (eq. 42 with random effects and eq. 46 with pooled cross sections). In order to control for the impact of media here, we use the number of households with a TV, which reveals less missing values than Internet users (especially for earlier years). The impact of the media on the number of Sites nominated in a given year is positive and significant, as expected. The coefficients of UN Security Council membership are somewhat ambiguous: Although the coefficient of being a permanent member is larger than the one of being a rotating member, only the coefficient of being a rotating member is significant. The coefficient of tourist expenditures is again negative and significant. 
To address the issue of reverse causality of the tourism variable, we introduce a oneyear lag of relative tourist expenditures (eq. 43 and 47). It seems very unlikely that a Site's nomination in a given year has an impact on the tourist expenditures in the year before. This effect would only occur if a Site is expected to be nominated. However, we did not find any evidence in the literature, travel guides, or newspapers that this might be the case. The coefficients of the lagged tourist expenditures confirm the negative and significant correlation with the number of Sites a country obtains in a given year.

In a last step, we introduce federalism (eq. 44 and 45 with random effects and eq. 48 and 49 with pooled cross section), but again this variable is associated with a considerable loss in the number observations. However, even in this specification, the sign (and often roughly the size) of the coefficients remains the same.

In addition to the problem of missing values, the panel regressions (in contrast to the cross-section estimations of the stock determinants) have to deal with a second issue, which decreases the likelihood of achieving significant coefficients: The time lag of the application process. Local politicians need time before a site is accepted on the country's tentative list and until it is officially nominated. After that, the Committee needs time to decide on the applications. The duration varies greatly between 12 months and eight years, as in the case of Dorset and East Devon Coast (UK) (see Leask and Fyall 2001). To be completely accurate, we would have to know the nomination process duration for every site and accordingly apply lagged independent variables (e.g., for Dorset, a lag of eight years). Because this information is not available, the estimates shown are necessarily an approximation of the real effect, which underestimates instead of overestimating the impact. In general, when controlling for historical, political, and economic determinants, the main results of the cross-section estimations are supported: Tourist expenditures are significant and negative; media distribution (in this case the percentage of households with TV) is positive and significant, and being a rotating member of the UN Security Council is positive and significant.

\section{CONCLUSION}

The implementation of the UNESCO World Heritage List to protect the common global heritage constitutes a great step forward toward preserving one of the most important global public goods on our planet. However, there are also negative aspects related to the List, such as the destruction of Sites (usually by increased deterioration) or substitution of funds away from sites not on the List. Here, we focus on the striking imbalance of the List. 
The distribution across continents and countries is highly unequal, which suggests that other factors than the 10 "objective” UNESCO criteria play a role.

We first investigate the historical reasons of why some countries may have more Sites than others do: The tenure of a country in the Convention, the size of the country, the number of years of high civilization, historical GDP, and historical population are all found to be positively correlated with the number of Sites. Although size is more important for the number of Natural Sites, historical GDP and population reflecting past development and cultural potential of a country are more important for Cultural Sites.

Using historical factors as controls, cross-section estimates are used to identify the stock determinants of getting on the List (total number of Sites in 2006 as a dependent variable). When simultaneously controlling for several factors, media distribution, federalism, and UN Security Council membership have a statistically positive effect on the number of Sites on the UNESCO List, whereas tourist expenditures have a significant and negative one. Panel-data models are able to estimate the flow determinants of being nominated for the List (number of Sites per year as a dependent variable). Even though there are problems due to the unequal and variable time lag from the beginning of the application process to the final nomination and missing values, the main results are confirmed. Although the media is positively correlated with the number of Sites per year, tourist expenditures are negative. In the panel specifications, the impact of being a rotating member of the UN Security Council is more robust than being a permanent member.

The analysis undertaken suggests that the List is not solely determined by cultural or historical factors but also by political and economic factors. These results are offered here for discussion. We do not normatively judge whether these factors should, or should not, have any influence on the selection of Sites on the World Heritage List. However, the claim that inclusion on the List is solely, or even mainly, "objectively" determined by the 10 criteria of the Convention is open to serious doubt. The empirical analysis, which shows that inclusion on the List is systematically correlated with economic and political factors unrelated to what "World Heritage" is claimed to be, suggests that extraneous factors play a significant role. This is not surprising as such but testifies to the importance of the World Heritage List. Countries find it necessary to try to influence the selection on the List exactly because the List is considered to be relevant. The World Heritage List should be looked at in this light, and it has to be discussed and an evaluation made of which economic and political influences are deemed to be legitimate and which are deemed to be unwarranted. To mitigate the impact of factors unrelated to the value of heritage, several approaches to reform the List are 
possible. For example, reduce the role of experts by conducting willingness-to-pay studies; limit the number Sites on the List to increase competition to get on or stay on the List; introduce World Culture Certificates to protect global heritage more efficiently (see Frey and Pamini 2009); or support countries with no Sites to apply for the List (which UNESCO actually has been doing since 1994, so far without significantly reducing the imbalance of the List).

This paper serves to raise our understanding of the political or economic factors that influence the composition of the List. It may help the decision makers involved in deciding about World Heritage issues to take steps to improve the selection of World Heritage Sites that truly reflect "the cultural and natural heritage around the world considered to be of outstanding value to humanity.” 


\section{APPENDIX}

The first six UNESCO criteria refer to Cultural Sites:

i. to represent a masterpiece of human creative genius;

ii. to exhibit an important interchange of human values, over a span of time or within a cultural area of the world, on developments in architecture or technology, monumental arts, town-planning or landscape design;

iii. to bear a unique or at least exceptional testimony to a cultural tradition or to a civilization which is living or which has disappeared;

iv. to be an outstanding example of a type of building, architectural or technological ensemble or landscape which illustrates (a) significant stage(s) in human history;

v. to be an outstanding example of a traditional human settlement, land-use, or sea-use which is representative of a culture (or cultures), or human interaction with the environment especially when it has become vulnerable under the impact of irreversible change;

vi. to be directly or tangibly associated with events or living traditions, with ideas, or with beliefs, with artistic and literary works of outstanding universal significance. (The Committee considers that this criterion should preferably be used in conjunction with other criteria);

The last four criteria concern Natural Sites:

vii. to contain superlative natural phenomena or areas of exceptional natural beauty and aesthetic importance;

viii. to be outstanding examples representing major stages of earth's history, including the record of life, significant on-going geological processes in the development of landforms, or significant geomorphic or physiographic features;

ix. to be outstanding examples representing significant on-going ecological and biological processes in the evolution and development of terrestrial, fresh water, coastal and marine ecosystems and communities of plants and animals;

x. to contain the most important and significant natural habitats for in-situ conservation of biological diversity, including those containing threatened species of outstanding universal value from the point of view of science or conservation. 
Table 1: The World Heritage List according to types of heritage and continents, 2010.

\begin{tabular}{ccccc}
\hline Region & Total Sites & Cultural Sites & Natural Sites & Mixed Sites \\
\hline Africa (sub-Saharan) & 81 & 43 & 35 & 3 \\
Americas & 162 & 101 & 57 & 4 \\
Asia and Pacific & 197 & 137 & 51 & 9 \\
Arabian Countries & 66 & 60 & 5 & 1 \\
Europe & 434 & 380 & 44 & 10 \\
\hline Total & 940 & 721 & 192 & 27 \\
\hline
\end{tabular}

Note: 21 Heritage Sites go across two countries each, one Site goes across 10 countries. This and all further tables count Sites as many times as the number of countries involved. We do not count the Old City of Jerusalem (ID 48) because it is associated with no country. Sites given to the Socialist Federal Republic of Yugoslavia are still counted under Serbia, although they now are listed under Croatia, Macedonia, Montenegro, and Slovenia. Itchan Kala (ID 543) is counted under Russia because in 1990 Uzbekistan still was part of it. We do not count the Bialowieza Forest (ID 33) for Belarus because in 1979 neither Belarus nor the USSR was in the World Heritage Convention. We do not count the Historic Center of Rome (ID 91) for the Holy See because in 1980 it was not yet a member of the World Heritage Convention. Although we are interested into the election process, we include the two delisted Sites (Arabian Oryx Sanctuary in Oman, listed in 1994 and delisted in 2007 ID 654, as well as Dresden Elbe Valley in Germany, listed in 2004 and delisted in 2009 ID 1156). Source: Frey and Pamini (2010), based on http://whc.unesco.org/en/list (accessed on August 30, 2010). 
Table 2: Countries with a large number (ten or more) of Sites in the World Heritage List, 2010.

\begin{tabular}{|c|c|c|c|c|}
\hline Country & Total & Cultural & Natural & Mixed \\
\hline Italy & 44 & 42 & 2 & 0 \\
\hline Spain & 41 & 36 & 3 & 2 \\
\hline China & 40 & 28 & 8 & 4 \\
\hline France & 35 & 31 & 3 & 1 \\
\hline Germany & 34 & 32 & 2 & 0 \\
\hline Mexico & 31 & 27 & 4 & 0 \\
\hline India & 28 & 23 & 5 & 0 \\
\hline United Kingdom & 28 & 23 & 4 & 1 \\
\hline Russia & 25 & 16 & 9 & 0 \\
\hline United States & 21 & 8 & 12 & 1 \\
\hline Australia & 18 & 3 & 11 & 4 \\
\hline Brazil & 18 & 11 & 7 & 0 \\
\hline Greece & 17 & 15 & 0 & 2 \\
\hline Canada & 15 & 6 & 9 & 0 \\
\hline Japan & 14 & 11 & 3 & 0 \\
\hline Sweden & 14 & 12 & 1 & 1 \\
\hline Poland & 13 & 12 & 1 & 0 \\
\hline Portugal & 13 & 12 & 1 & 0 \\
\hline Czech Republic & 12 & 12 & 0 & 0 \\
\hline Iran & 12 & 12 & 0 & 0 \\
\hline Peru & 11 & 7 & 2 & 2 \\
\hline Yugoslavia & 11 & 7 & 3 & 1 \\
\hline Belgium & 10 & 10 & 0 & 0 \\
\hline South Korea & 10 & 9 & 1 & 0 \\
\hline Switzerland & 10 & 7 & 3 & 0 \\
\hline Selection Total & 525 & 412 & 94 & 19 \\
\hline World Heritage Total & 940 & 721 & 192 & 27 \\
\hline \multicolumn{5}{|c|}{$\begin{array}{l}\text { Note: The same remarks as for Table } 1 \text { apply. Under Yugoslavia we consider the Sites } \\
\text { of the whole Socialist Federal Republic of Yugoslavia and those of Serbia after the } \\
\text { country disintegration. } \\
\text { Source: Frey and Pamini (2010), based on http://whc.unesco.org/en/list, accessed on } \\
\text { 30.8.2010. }\end{array}$} \\
\hline
\end{tabular}


Table 3: Countries with no or only one Cultural Site in the World Heritage List, 2010

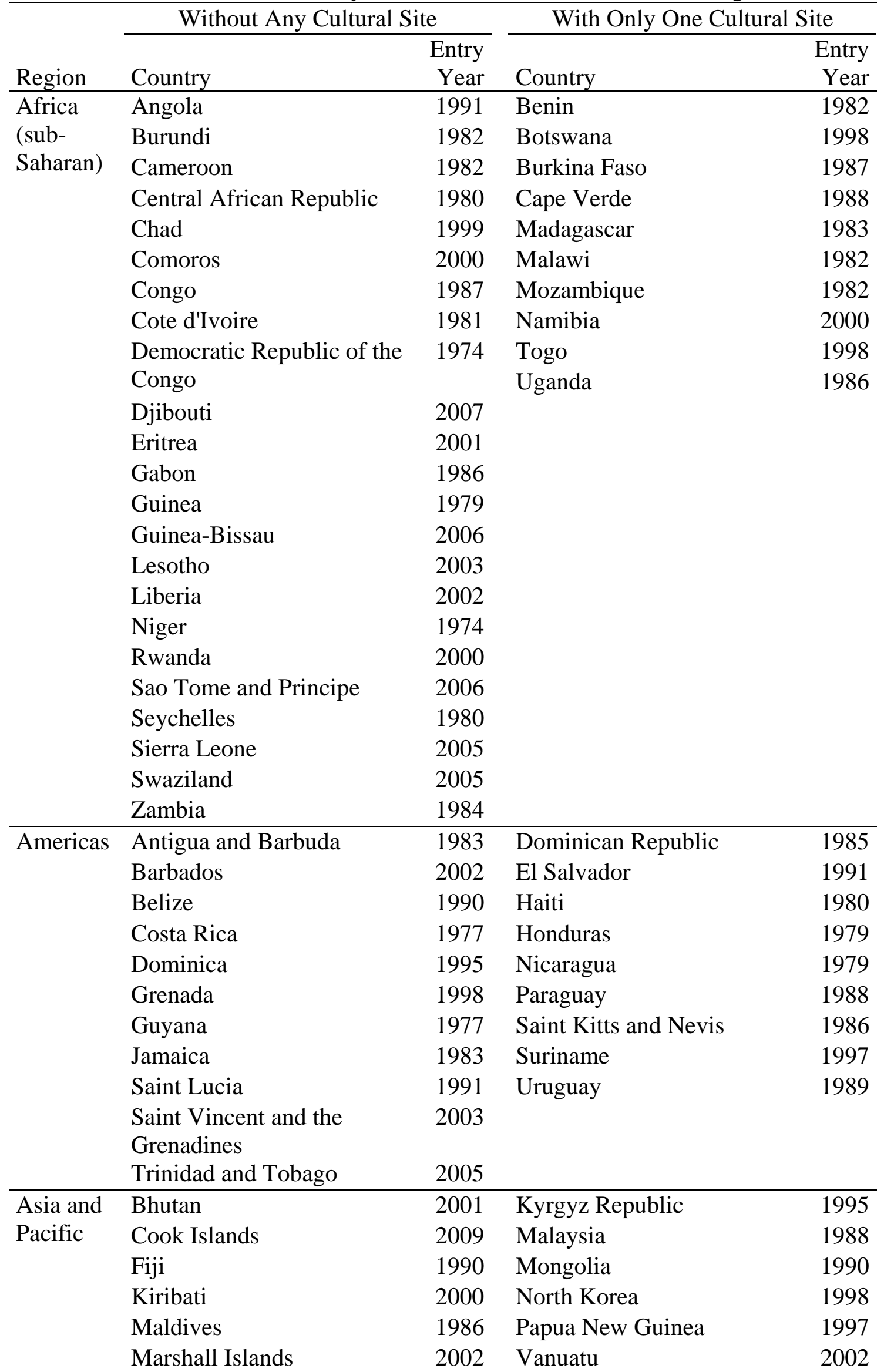




\begin{tabular}{|c|c|c|c|c|}
\hline & Micronesia & \multicolumn{3}{|l|}{2002} \\
\hline & Myanmar & \multicolumn{3}{|l|}{1994} \\
\hline & New Zealand & \multicolumn{3}{|l|}{1984} \\
\hline & Niue & \multicolumn{3}{|l|}{2001} \\
\hline & Palau & \multicolumn{3}{|l|}{2002} \\
\hline & Samoa & \multicolumn{3}{|l|}{2001} \\
\hline & Solomon Islands & \multicolumn{3}{|l|}{1992} \\
\hline & Tajikistan & \multicolumn{3}{|l|}{1992} \\
\hline & Tonga & \multicolumn{3}{|l|}{2004} \\
\hline \multirow{4}{*}{$\begin{array}{l}\text { Arabian } \\
\text { Countries }\end{array}$} & Kuwait & 2002 & Bahrain & 1991 \\
\hline & Qatar & 1984 & Mauritania & 1981 \\
\hline & United Arab Emirates & 2001 & Saudi Arabia & 1978 \\
\hline & & & Sudan & 1974 \\
\hline \multirow[t]{6}{*}{ Europe } & Macedonia & 1997 & Andorra & 1997 \\
\hline & Monaco & 1978 & Iceland & 1995 \\
\hline & Montenegro & 2006 & Luxembourg & 1983 \\
\hline & Slovenia & 1992 & Moldova & 2002 \\
\hline & & & San Marino & 1991 \\
\hline & & & Vatican & 1982 \\
\hline
\end{tabular}

Note: The same remarks as for Table 1 apply. Montenegro has a Cultural Site that has been listed at the time of the Socialist Federal Republic of Yugoslavia and is not counted here.

Source: Frey and Pamini (2010), based on http://whc.unesco.org/en/list (accessed on August 8, 2010). 
Table 4: Historical determinants of a countries number of Cultural and Natural Sites in the World Heritage List 2006

\begin{tabular}{|c|c|c|c|c|c|c|c|c|c|c|c|c|}
\hline & $\begin{array}{c}(1) \\
\text { Cultural }\end{array}$ & $\begin{array}{c}(2) \\
\text { Natural }\end{array}$ & $\begin{array}{c}\text { (3) } \\
\text { Cultural }\end{array}$ & $\begin{array}{c}(4) \\
\text { Natural }\end{array}$ & $\begin{array}{c}\text { (5) } \\
\text { Cultural }\end{array}$ & $\begin{array}{c}(6) \\
\text { Natural }\end{array}$ & $\begin{array}{c}(7) \\
\text { Cultural }\end{array}$ & $\begin{array}{c}(8) \\
\text { Natural }\end{array}$ & $\begin{array}{c}(9) \\
\text { Cultural }\end{array}$ & $\begin{array}{c}(10) \\
\text { Natural }\end{array}$ & $\begin{array}{c}\text { (11) } \\
\text { Cultural }\end{array}$ & $\begin{array}{c}(12) \\
\text { Natural }\end{array}$ \\
\hline $\begin{array}{l}\text { \# Years in } \\
\text { Convention }\end{array}$ & $\begin{array}{c}0.0854 * * * \\
(7.531)\end{array}$ & $\begin{array}{c}0.0879 * * * \\
(7.867)\end{array}$ & $\begin{array}{c}0.0590 * * * \\
(5.364)\end{array}$ & $\begin{array}{c}0.0773^{* * * *} \\
(5.940)\end{array}$ & $\begin{array}{l}0.0267 \\
(1.214)\end{array}$ & $\begin{array}{c}0.0434 * \\
(1.791)\end{array}$ & $\begin{array}{c}0.0454 * * \\
(2.443)\end{array}$ & $\begin{array}{l}0.0195 \\
(0.960)\end{array}$ & $\begin{array}{l}0.0267 \\
(1.512)\end{array}$ & $\begin{array}{l}0.0251 \\
(1.275)\end{array}$ & $\begin{array}{c}0.0432 * * * \\
(2.686)\end{array}$ & $\begin{array}{c}0.0371^{* *} \\
(2.139)\end{array}$ \\
\hline $\begin{array}{l}\text { Size of country } \\
\text { (in million sqk) }\end{array}$ & $\begin{array}{c}0.141^{* * *} \\
(3.171)\end{array}$ & $\begin{array}{c}0.187 * * * \\
(11.31)\end{array}$ & $\begin{array}{c}0.111^{* * *} \\
(2.743)\end{array}$ & $\begin{array}{c}0.218 * * * \\
(6.988)\end{array}$ & $\begin{array}{c}0.0422 \\
(1.239)\end{array}$ & $\begin{array}{c}0.151^{* * *} \\
(5.229)\end{array}$ & $\begin{array}{c}0.0659 * \\
(1.849)\end{array}$ & $\begin{array}{c}0.186 * * * \\
(5.955)\end{array}$ & $\begin{array}{l}-0.0146 \\
(-0.444)\end{array}$ & $\begin{array}{c}0.171^{* * *} \\
(5.713)\end{array}$ & $\begin{array}{c}0.00477 \\
(0.128)\end{array}$ & $\begin{array}{c}0.185^{* * *} \\
(6.099)\end{array}$ \\
\hline Africa & $\begin{array}{c}-2.008^{* * * *} \\
(-7.947)\end{array}$ & $\begin{array}{l}0.0983 \\
(0.413)\end{array}$ & & & & & & & & & & \\
\hline America & $\begin{array}{c}-1.459 * * * \\
(-6.109)\end{array}$ & $\begin{array}{c}0.162 \\
(0.764)\end{array}$ & & & & & & & & & & \\
\hline Asia/Pacific & $\begin{array}{c}-0.902 * * * \\
(-3.988)\end{array}$ & $\begin{array}{c}0.427 * * \\
(2.010)\end{array}$ & & & & & & & & & & \\
\hline Arabian & $\begin{array}{c}-1.454^{* * *} \\
(-4.995)\end{array}$ & $\begin{array}{c}-1.551^{* * *} \\
(-3.215)\end{array}$ & & & & & & & & & & \\
\hline Europe & (refer & ence) & & & & & & & & & & \\
\hline $\begin{array}{l}\text { \# Years of high } \\
\text { civilization }\end{array}$ & & & $\begin{array}{c}0.000543^{* * *} \\
(7.216)\end{array}$ & $\begin{array}{c}-9.85 e-05 \\
(-1.393)\end{array}$ & & & & & & & & \\
\hline $\begin{array}{l}\text { GDP per capita } \\
\text { in year } 1500\end{array}$ & & & & & $\begin{array}{c}0.00266^{* * *} \\
(2.956)\end{array}$ & $\begin{array}{c}-0.000469 \\
(-0.454)\end{array}$ & & & & & & \\
\hline $\begin{array}{l}\text { GDP per capita } \\
\text { in year } 1820\end{array}$ & & & & & & & $\begin{array}{c}0.00150^{* * *} \\
(3.669)\end{array}$ & $\begin{array}{c}0.000461 \\
(1.251)\end{array}$ & & & & \\
\hline $\begin{array}{l}\text { Population in } \\
\text { year } 1500\end{array}$ & & & & & & & & & $\begin{array}{c}1.58 \mathrm{e}-05^{* *} \\
(2.244)\end{array}$ & $\begin{array}{c}4.84 \mathrm{e}-06 \\
(1.095)\end{array}$ & & \\
\hline $\begin{array}{l}\text { Population in } \\
\text { year } 1820\end{array}$ & & & & & & & & & & & $\begin{array}{c}7.82 \mathrm{e}-06^{* *} \\
(2.196)\end{array}$ & $\begin{array}{c}1.56 \mathrm{e}-06 \\
(0.969)\end{array}$ \\
\hline Constant & $\begin{array}{c}0.178 \\
(0.685)\end{array}$ & $\begin{array}{c}-2.318 * * * \\
(-7.814)\end{array}$ & $\begin{array}{c}-0.725^{* * *} \\
(-3.008)\end{array}$ & $\begin{array}{c}-1.974 * * * \\
(-6.293)\end{array}$ & $\begin{array}{c}0.171 \\
(0.201)\end{array}$ & $\begin{array}{c}-0.374 \\
(-0.375)\end{array}$ & $\begin{array}{c}-0.196 \\
(-0.335)\end{array}$ & $\begin{array}{c}-0.609 \\
(-1.054)\end{array}$ & $\begin{array}{c}1.531 * * * \\
(3.433)\end{array}$ & $\begin{array}{c}-0.400 \\
(-0.789)\end{array}$ & $\begin{array}{l}0.737 * \\
(1.875)\end{array}$ & $\begin{array}{l}-0.846^{*} \\
(-1.935)\end{array}$ \\
\hline Observations & 182 & 182 & 182 & 182 & 32 & 32 & 50 & 50 & 50 & 50 & 87 & 87 \\
\hline
\end{tabular}

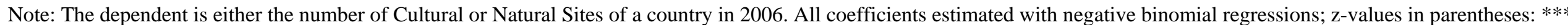
$\mathrm{p}<0.01,{ }^{* *} \mathrm{p}<0.05,{ }^{*} \mathrm{p}<0.1$. The same remarks as for Table 1 apply. All regressions refer only to the countries parties of the World Heritage Convention in 2006 .

Source: http://whc.unesco.org/en/list, accessed on 30.8.2010. World Bank Development Indicators, O’Brien (2002) , Maddison (2007). 
Table 5: Economic determinants of a countries number of total Sites in the World Heritage List 2006

\begin{tabular}{|c|c|c|c|c|c|c|c|}
\hline & $\begin{array}{c}\text { (13) } \\
\text { Total Sites }\end{array}$ & $\begin{array}{c}(14) \\
\text { Total Sites }\end{array}$ & $\begin{array}{c}\text { (15) } \\
\text { Total Sites }\end{array}$ & $\begin{array}{c}(16) \\
\text { Total Sites }\end{array}$ & $\begin{array}{c}(17) \\
\text { Total Sites }\end{array}$ & $\begin{array}{c}\text { (18) } \\
\text { Total Sites }\end{array}$ & $\begin{array}{c}(19) \\
\text { Total Sites }\end{array}$ \\
\hline GDP & $\begin{array}{c}0.000377^{* * *} \\
(2.825)\end{array}$ & & & & & & $\begin{array}{c}0.000247 * * \\
(2.151)\end{array}$ \\
\hline GDP per capita & & $\begin{array}{c}0.0321^{* * *} \\
(4.361)\end{array}$ & & & & & $\begin{array}{c}-0.00868 \\
(-0.786)\end{array}$ \\
\hline \# Tourists & & & $\begin{array}{l}4.04 \mathrm{e}-05^{* * *} \\
(5.444)\end{array}$ & & & & \\
\hline $\begin{array}{l}\text { \# Tourists / } \\
\text { population }\end{array}$ & & & & $\begin{array}{c}-63.56 \\
(-1.302)\end{array}$ & & & \\
\hline $\begin{array}{l}\text { Tourists expend / } \\
\text { exports }\end{array}$ & & & & & $\begin{array}{c}-0.0267 * * * \\
(-4.073)\end{array}$ & & $\begin{array}{c}-0.0223 * * * \\
(-3.281)\end{array}$ \\
\hline $\begin{array}{l}\text { Globalization } \\
\text { index }\end{array}$ & & & & & & $\begin{array}{c}0.0292^{* * *} \\
(5.381)\end{array}$ & $\begin{array}{c}0.0288^{* * * *} \\
(3.645)\end{array}$ \\
\hline $\begin{array}{l}\text { \# Years in } \\
\text { Convention }\end{array}$ & $\begin{array}{c}0.0619 * * * \\
(6.390)\end{array}$ & $\begin{array}{c}0.0648^{* * * *} \\
(6.820)\end{array}$ & $\begin{array}{c}0.0551^{* * *} \\
(6.308)\end{array}$ & $\begin{array}{c}0.0644 * * * \\
(6.400)\end{array}$ & $\begin{array}{c}0.0560 * * * \\
(5.268)\end{array}$ & $\begin{array}{c}0.0618 * * * \\
(6.185)\end{array}$ & $\begin{array}{c}0.0543 * * * \\
(5.389)\end{array}$ \\
\hline $\begin{array}{l}\text { Size of country (in } \\
\text { million sqk) }\end{array}$ & $\begin{array}{c}0.113^{* * * *} \\
(3.295)\end{array}$ & $\begin{array}{c}0.144^{* * *} \\
(4.296)\end{array}$ & $\begin{array}{c}0.0893 * * * \\
(2.798)\end{array}$ & $\begin{array}{c}0.140 * * * \\
(3.785)\end{array}$ & $\begin{array}{c}0.120 * * * \\
(3.399)\end{array}$ & $\begin{array}{c}0.147 * * * \\
(4.307)\end{array}$ & $\begin{array}{c}0.0958^{* * * *} \\
(3.086)\end{array}$ \\
\hline $\begin{array}{l}\text { \# Years of high } \\
\text { civilization }\end{array}$ & $\begin{array}{l}0.000350^{* * * *} \\
\quad(5.467)\end{array}$ & $\begin{array}{l}0.000316^{* * * *} \\
\quad(5.293)\end{array}$ & $\begin{array}{l}0.000221^{* * *} \\
\quad(3.802)\end{array}$ & $\begin{array}{l}0.000427^{* * *} \\
\quad(6.468)\end{array}$ & $\begin{array}{l}0.000366^{* * *} \\
(5.935)\end{array}$ & $\begin{array}{l}0.000250^{* * * *} \\
\quad(4.216)\end{array}$ & $\begin{array}{l}0.000221^{* * *} \\
\quad(3.850)\end{array}$ \\
\hline Constant & $\begin{array}{l}-0.416^{*} \\
(-1.953)\end{array}$ & $\begin{array}{c}-0.622 * * * \\
(-2.881)\end{array}$ & $\begin{array}{c}-0.275 \\
(-1.422)\end{array}$ & $\begin{array}{l}-0.374^{*} \\
(-1.677)\end{array}$ & $\begin{array}{c}0.204 \\
(0.814)\end{array}$ & $\begin{array}{c}-2.083^{* * *} \\
(-4.892)\end{array}$ & $\begin{array}{c}-1.547 * * * \\
(-2.907)\end{array}$ \\
\hline Observations & 169 & 169 & 168 & 168 & 146 & 153 & 133 \\
\hline
\end{tabular}


Table 6: Political determinants of a countries number of total Sites in the World Heritage List 2006

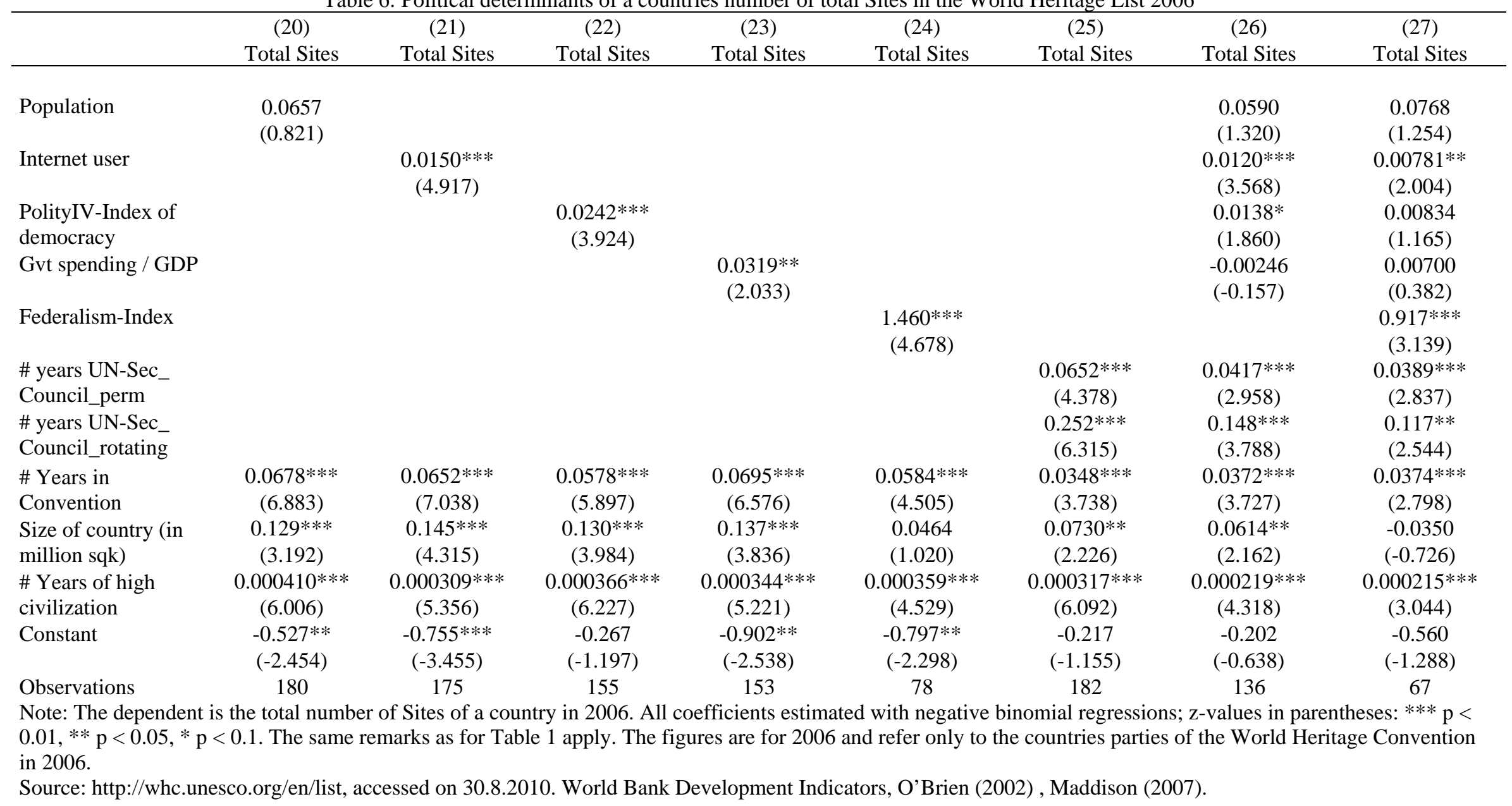


Table 7: Economic and political determinants of a countries number of total Sites in the World Heritage List 2006

(28) (29)

Total Sites

Total Sites

GDP
Tourists expend /
exports
Internet user
\# years UN-Sec_-
Council_perm
\# years UN-Sec_-
Council_rotating
Federalism
\# Years in Convention
Size of country (in
million sqk)
\# Years of high
civilization
Constant

$-2.91 \mathrm{e}-05$
$(-0.408)$
$-0.0155^{* * *}$
$(-2.766)$
$0.00954 * * *$
$(3.316)$
$0.0524 * * *$
$(3.271)$
$0.185^{* * *}$
$(4.485)$


$0.0282^{* * *}$
$(2.817)$
$0.0693^{* *}$
$(2.332)$
$0.000255^{* * *}$
$(5.388)$
0.155
$(0.670)$
139

$-2.66 \mathrm{e}-05$

$(-0.461)$

$-0.00388$

$(-0.492)$

$0.00705^{* *}$

(2.155)

$0.0512 * * *$

(3.526)

$0.139 * * *$

(3.002)

$1.072 * * *$

(3.603)

$0.0297 * *$

(2.337)

0.00576

(0.147)

0.000240 ***

(3.855)

$-0.369$

$(-1.063)$

Observations

139

64

Note: The dependent is the total number of Sites of a country in 2006. All coefficients estimated with negative binomial regressions; $\mathrm{z}$-values in parentheses: ${ }^{* * *} \mathrm{p}<0.01,{ }^{* *} \mathrm{p}<0.05, * \mathrm{p}<0.1$. The same remarks as for Table 1 apply. The figures are for 2006 and refer only to the countries parties of the World Heritage Convention in 2006.

Source: http://whc.unesco.org/en/list, accessed on 30.8.2010. World Bank Development Indicators, O’Brien (2002), Maddison (2007). 
Table 8: Panel estimations of the historical determinants of the yearly nominations of Cultural and Natural Sites in the World Heritage List per country until 2006

\begin{tabular}{|c|c|c|c|c|c|c|c|c|c|c|c|c|}
\hline & $\begin{array}{c}(30) \\
\text { Cultural } \\
\end{array}$ & $\begin{array}{c}(31) \\
\text { Natural } \\
\end{array}$ & $\begin{array}{c}(32) \\
\text { Cultural } \\
\end{array}$ & $\begin{array}{c}(33) \\
\text { Natural } \\
\end{array}$ & $\begin{array}{c}\text { (34) } \\
\text { Cultural } \\
\end{array}$ & $\begin{array}{c}\text { (35) } \\
\text { Natural } \\
\end{array}$ & $\begin{array}{c}\text { (36) } \\
\text { Cultural } \\
\end{array}$ & $\begin{array}{c}(37) \\
\text { Natural } \\
\end{array}$ & $\begin{array}{c}(38) \\
\text { Cultural } \\
\end{array}$ & $\begin{array}{c}\text { (39) } \\
\text { Natural } \\
\end{array}$ & $\begin{array}{c}(40) \\
\text { Cultural } \\
\end{array}$ & $\begin{array}{c}(41) \\
\text { Natural } \\
\end{array}$ \\
\hline $\begin{array}{l}\text { \# Years in } \\
\text { Convention }\end{array}$ & $\begin{array}{c}-0.00456 \\
(-0.774)\end{array}$ & $\begin{array}{c}-0.0221 * * \\
(-2.128)\end{array}$ & $\begin{array}{c}-0.00965 * \\
(-1.665)\end{array}$ & $\begin{array}{c}-0.0258^{* *} \\
(-2.539)\end{array}$ & $\begin{array}{c}-0.00193 \\
(-0.258)\end{array}$ & $\begin{array}{c}-0.00283 \\
(-0.198)\end{array}$ & $\begin{array}{c}-0.00539 \\
(-0.760)\end{array}$ & $\begin{array}{l}-0.0127 \\
(-0.991)\end{array}$ & $\begin{array}{c}-0.0120^{*} \\
(-1.764)\end{array}$ & $\begin{array}{c}-0.0236^{*} \\
(-1.851)\end{array}$ & $\begin{array}{c}-0.0123^{*} \\
(-1.955)\end{array}$ & $\begin{array}{c}-0.0213^{*} \\
(-1.923)\end{array}$ \\
\hline $\begin{array}{l}\text { Size of country } \\
\text { (in million sqk) }\end{array}$ & $\begin{array}{c}0.146 * * * \\
(3.663)\end{array}$ & $\begin{array}{c}0.213^{* * *} \\
(8.142)\end{array}$ & $\begin{array}{c}0.106^{* * * *} \\
(3.091)\end{array}$ & $\begin{array}{c}0.240 * * * \\
(7.261)\end{array}$ & $\begin{array}{l}0.0226 \\
(0.745)\end{array}$ & $\begin{array}{c}0.140 * * * \\
(5.100)\end{array}$ & $\begin{array}{l}0.0518 * \\
(1.759)\end{array}$ & $\begin{array}{c}0.179 * * * \\
(6.588)\end{array}$ & $\begin{array}{c}-0.00821 \\
(-0.283)\end{array}$ & $\begin{array}{c}0.176 * * * \\
(6.044)\end{array}$ & $\begin{array}{l}0.0187 \\
(0.565)\end{array}$ & $\begin{array}{c}0.195 * * * \\
(6.383)\end{array}$ \\
\hline Africa & $\begin{array}{c}-1.863 * * * \\
(-7.690)\end{array}$ & $\begin{array}{c}0.352 \\
(1.255)\end{array}$ & & & & & & & & & & \\
\hline America & $\begin{array}{c}-1.014 * * * \\
(-4.644)\end{array}$ & $\begin{array}{c}0.473^{*} \\
(1.739)\end{array}$ & & & & & & & & & & \\
\hline Asia/Pacific & $\begin{array}{c}-1.080 * * * \\
(-5.085)\end{array}$ & $\begin{array}{c}0.435 \\
(1.538)\end{array}$ & & & & & & & & & & \\
\hline Arabian & $\begin{array}{c}-1.236 * * * \\
(-4.840)\end{array}$ & $\begin{array}{c}-1.146 * * \\
(-2.095)\end{array}$ & & & & & & & & & & \\
\hline Europe & (ref & nce) & & & & & & & & & & \\
\hline $\begin{array}{l}\text { \# Years of high } \\
\text { civilization }\end{array}$ & & & $\begin{array}{c}0.000371^{* * *} \\
(6.057)\end{array}$ & $\begin{array}{c}-0.000128 \\
(-1.606)\end{array}$ & & & & & & & & \\
\hline $\begin{array}{l}\text { GDP per capita } \\
\text { in year } 1500\end{array}$ & & & & & $\begin{array}{c}0.00172^{* *} \\
(2.291)\end{array}$ & $\begin{array}{c}-0.00168 \\
(-1.419)\end{array}$ & & & & & & \\
\hline $\begin{array}{l}\text { GDP per capita } \\
\text { in year } 1820\end{array}$ & & & & & & & $\begin{array}{c}0.00149 * * * \\
(4.434)\end{array}$ & $\begin{array}{c}0.000302 \\
(0.765)\end{array}$ & & & & \\
\hline $\begin{array}{l}\text { Population in } \\
\text { year } 1500\end{array}$ & & & & & & & & & $\begin{array}{c}9.18 \mathrm{e}-06^{*} \\
(1.879)\end{array}$ & $\begin{array}{c}8.26 e-07 \\
(0.170)\end{array}$ & & \\
\hline $\begin{array}{l}\text { Population in } \\
\text { year } 1820\end{array}$ & & & & & & & & & & & $\begin{array}{c}3.80 \mathrm{e}-06 * \\
(1.807)\end{array}$ & $\begin{array}{l}1.40 \mathrm{e}-07 \\
(0.0816)\end{array}$ \\
\hline Constant & $\begin{array}{l}-0.0230 \\
(-0.118)\end{array}$ & $\begin{array}{c}-1.355^{* * *} \\
(-2.603)\end{array}$ & $\begin{array}{c}-1.041 * * * \\
(-5.365)\end{array}$ & $\begin{array}{c}-0.912 * * \\
(-1.973)\end{array}$ & $\begin{array}{l}-1.071^{*} \\
(-1.907)\end{array}$ & $\begin{array}{c}-0.501 \\
(-0.587)\end{array}$ & $\begin{array}{c}-1.552 * * * \\
(-4.408)\end{array}$ & $\begin{array}{c}-1.415^{* *} \\
(-2.233)\end{array}$ & $\begin{array}{c}-0.117 \\
(-0.550)\end{array}$ & $\begin{array}{l}-0.937 * \\
(-1.651)\end{array}$ & $\begin{array}{c}-0.281 \\
(-1.444)\end{array}$ & $\begin{array}{c}-0.714 \\
(-1.210)\end{array}$ \\
\hline Observations & 3,756 & 3,756 & 3,756 & 3,756 & 827 & 827 & 1,245 & 1,245 & 1,263 & 1,263 & 2,149 & 2,149 \\
\hline Number of id & 183 & 183 & 183 & 183 & 32 & 32 & 50 & 50 & 50 & 50 & 87 & 87 \\
\hline
\end{tabular}

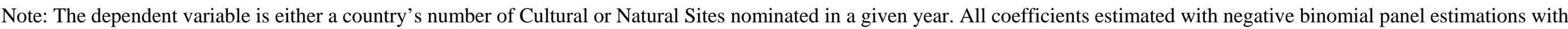

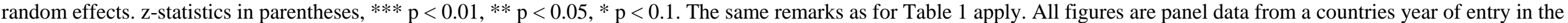

World Heritage Convention until 2006.

Source: http://whc.unesco.org/en/list, accessed on 30.8.2010. World Bank Development Indicators, O’Brien (2002) , Maddison (2007). 
Table 9: Panel estimations of the economical and political determinants of yearly nominated Sites in the World Heritage List until 2006

\begin{tabular}{|c|c|c|c|c|c|c|c|c|}
\hline & $\begin{array}{c}(42) \\
\text { Panel, RE }\end{array}$ & $\begin{array}{c}\text { (43) } \\
\text { Panel, RE } \\
\end{array}$ & $\begin{array}{c}(44) \\
\text { Panel, RE }\end{array}$ & $\begin{array}{c}(45) \\
\text { Panel, RE }\end{array}$ & $\begin{array}{c}(46) \\
\text { Pooled } \\
\end{array}$ & $\begin{array}{c}(47) \\
\text { Pooled } \\
\end{array}$ & $\begin{array}{c}(48) \\
\text { Pooled } \\
\end{array}$ & $\begin{array}{c}(49) \\
\text { Pooled } \\
\end{array}$ \\
\hline GDP & $\begin{array}{l}6.82 \mathrm{e}-05 \\
(0.594)\end{array}$ & $\begin{array}{c}9.51 \mathrm{e}-05 \\
(0.637)\end{array}$ & $\begin{array}{l}-4.66 e-07 \\
(-0.00410)\end{array}$ & $\begin{array}{c}-2.83 e-05 \\
(-0.209)\end{array}$ & $\begin{array}{c}5.08 \mathrm{e}-05 \\
(0.485)\end{array}$ & $\begin{array}{l}4.36 \mathrm{e}-05 \\
(0.355)\end{array}$ & $\begin{array}{c}5.93 \mathrm{e}-05 \\
(0.945)\end{array}$ & $\begin{array}{l}4.55 \mathrm{e}-05 \\
(0.545)\end{array}$ \\
\hline $\begin{array}{l}\text { Tourists expend } \\
\text { / exports }\end{array}$ & $\begin{array}{c}-0.0252 * * * \\
(-2.798)\end{array}$ & & $\begin{array}{l}-0.0205 \\
(-1.567)\end{array}$ & & $\begin{array}{c}-0.0287 * * * \\
(-3.486)\end{array}$ & & $\begin{array}{l}-0.0134 \\
(-1.179)\end{array}$ & \\
\hline $\begin{array}{l}\text { Lag Tourists } \\
\text { expend / exports }\end{array}$ & & $\begin{array}{c}-0.0222 * * \\
(-2.313)\end{array}$ & & $\begin{array}{l}-0.0164 \\
(-1.213)\end{array}$ & & $\begin{array}{c}-0.0278 * * * \\
(-2.984)\end{array}$ & & $\begin{array}{l}-0.00915 \\
(-0.791)\end{array}$ \\
\hline TV per $\mathrm{HH}$ & $\begin{array}{c}0.0116^{* * *} \\
(3.432)\end{array}$ & $\begin{array}{c}0.0109 * * * \\
(2.982)\end{array}$ & $\begin{array}{c}0.00841^{*} \\
(1.748)\end{array}$ & $\begin{array}{l}0.00585 \\
(1.134)\end{array}$ & $\begin{array}{c}0.0148 * * * \\
(3.246)\end{array}$ & $\begin{array}{c}0.0137 * * * \\
(2.877)\end{array}$ & $\begin{array}{l}0.0162 * \\
(1.925)\end{array}$ & $\begin{array}{l}0.0127 \\
(1.519)\end{array}$ \\
\hline $\begin{array}{l}\text { UN-Security } \\
\text { Council_perm }\end{array}$ & $\begin{array}{c}0.596 \\
(1.272)\end{array}$ & $\begin{array}{c}0.466 \\
(0.913)\end{array}$ & $\begin{array}{c}0.742 \\
(1.399)\end{array}$ & $\begin{array}{c}0.759 \\
(1.318)\end{array}$ & $\begin{array}{c}0.227 \\
(0.694)\end{array}$ & $\begin{array}{c}0.173 \\
(0.484)\end{array}$ & $\begin{array}{c}0.226 \\
(0.919)\end{array}$ & $\begin{array}{c}0.288 \\
(1.280)\end{array}$ \\
\hline UN-Security & $0.322 *$ & 0.314 & 0.241 & 0.203 & $0.424 * * *$ & $0.392^{* *}$ & 0.209 & 0.183 \\
\hline Council_rotating & $(1.724)$ & $(1.581)$ & $(1.030)$ & $(0.795)$ & $(2.644)$ & (2.038) & $(1.360)$ & $(0.870)$ \\
\hline $\begin{array}{l}\text { Federalism- } \\
\text { index }\end{array}$ & & & $\begin{array}{c}0.637 \\
(1.318)\end{array}$ & $\begin{array}{c}0.657 \\
(1.285)\end{array}$ & & & $\begin{array}{c}0.307 \\
(0.713)\end{array}$ & $\begin{array}{c}0.376 \\
(0.820)\end{array}$ \\
\hline $\begin{array}{l}\text { \# Years in } \\
\text { Convention }\end{array}$ & $\begin{array}{c}-0.0271 * * \\
(-2.446)\end{array}$ & $\begin{array}{c}-0.0332 * * * \\
(-2.682)\end{array}$ & $\begin{array}{c}-0.0407^{* * *} \\
(-2.664)\end{array}$ & $\begin{array}{c}-0.0428 * * * \\
(-2.602)\end{array}$ & $\begin{array}{l}0.0138 \\
(1.081)\end{array}$ & $\begin{array}{l}0.0124 \\
(0.883)\end{array}$ & $\begin{array}{c}0.00315 \\
(0.174)\end{array}$ & $\begin{array}{l}-0.000905 \\
(-0.0463)\end{array}$ \\
\hline $\begin{array}{l}\text { Size of country } \\
\text { (in million sqk) }\end{array}$ & $\begin{array}{c}0.0775 * \\
(1.769)\end{array}$ & $\begin{array}{c}0.0941^{*} \\
(1.927)\end{array}$ & $\begin{array}{l}-0.0358 \\
(-0.467)\end{array}$ & $\begin{array}{l}-0.0777 \\
(-0.918)\end{array}$ & $\begin{array}{c}0.0609 * * * \\
(2.863)\end{array}$ & $\begin{array}{c}0.0713 * * * \\
(2.821)\end{array}$ & $\begin{array}{l}-0.0400 \\
(-0.866)\end{array}$ & $\begin{array}{l}-0.0547 \\
(-0.995)\end{array}$ \\
\hline $\begin{array}{l}\text { \# Years of high } \\
\text { civilization }\end{array}$ & $\begin{array}{c}0.000261 * * * \\
(3.313)\end{array}$ & $\begin{array}{c}0.000281 * * * \\
(3.211)\end{array}$ & $\begin{array}{l}0.000405^{* * * *} \\
(3.102)\end{array}$ & $\begin{array}{c}0.000476 * * * \\
(3.295)\end{array}$ & $\begin{array}{c}0.000218^{* *} \\
(2.214)\end{array}$ & $\begin{array}{c}0.000220^{* *} \\
(2.158)\end{array}$ & $\begin{array}{l}0.000494 * * * \\
(2.748)\end{array}$ & $\begin{array}{c}0.000539 * * * \\
(2.815)\end{array}$ \\
\hline Constant & $\begin{array}{c}0.189 \\
(0.329)\end{array}$ & $\begin{array}{c}0.591 \\
(0.835)\end{array}$ & $\begin{array}{c}0.540 \\
(0.593)\end{array}$ & $\begin{array}{c}1.088 \\
(0.868)\end{array}$ & $\begin{array}{c}194.9 * * * \\
(4.197)\end{array}$ & $\begin{array}{c}221.3^{* * * *} \\
(4.062)\end{array}$ & $\begin{array}{c}199.2 * * * \\
(3.230)\end{array}$ & $\begin{array}{c}199.5^{* * *} \\
(2.983)\end{array}$ \\
\hline $\begin{array}{l}\text { Observations } \\
\text { Number of id }\end{array}$ & $\begin{array}{c}1,390 \\
153\end{array}$ & $\begin{array}{c}1,274 \\
150\end{array}$ & $\begin{array}{c}700 \\
71\end{array}$ & $\begin{array}{c}645 \\
71\end{array}$ & 1,390 & 1,274 & 700 & 645 \\
\hline
\end{tabular}

Note: The dependent variable is a country's total number of Sites nominated in a given year. The coefficients (42)-(45) are estimated with negative binomial panel

estimations with random effects, the coefficients (46)-(49) show negative binomial pooled cross section estimates. The pooled estimates also contain year and continent fixed effects.

z-statistics in parentheses, ${ }^{* * *} \mathrm{p}<0.01,{ }^{* *} \mathrm{p}<0.05{ }^{*} \mathrm{p}<0.1$. The same remarks as for Table 1 apply. All figures are panel data from a countries year of entry in the World Heritage Convention until 2006

Source: http://whc.unesco.org/en/list, accessed on 30.8.2010. World Bank Development Indicators, O’Brien (2002) , Maddison (2007). 


\section{LITERATURE}

Arezki, Rabah, Reda Cherif, and John Piotrowski. 2009. Tourism Specialization and Economic Development: Evidence from the UNESCO World Heritage List. Working paper, International Monetary Fund.

Ashworth, Gregory John, and Bart J. M. van der Aa. 2006. Strategy and policy for the world heritage convention: goals, practices and future solutions. In Managing World Heritage Sites, ed. Anna Leask and Alan Fyall. London, England: Elsevier.

Beck, Thorsten, George Clarke, Alberto Groff, Philip Keefer, and Patrick Walsh. 2001. New Tools in Comparative Political Economy: The Database of Political Institutions. World Bank Economic Review 15:165-176.

Benhamou, Françoise. 1996. Is Increased Public Spending for the Preservation of Historic Monuments Inevitable? The French Case. Journal of Cultural Economics 20:115-131.

- 2003. Heritage. In A Handbook of Cultural Economics, ed. Ruth Towse. Cheltenham, England, and Northampton, MA: Edward Elgar.

Bonet, Lluis. 2003. Cultural tourism. In A Handbook of Cultural Economics, ed. Ruth Towse. Cheltenham, England, and Northampton, MA: Edward Elgar.

Buchanan, James M. 1980. Rent Seeking and Profit Seeking. In Toward a Theory of the RentSeeking Society, ed. James M. Buchanan, Robert M. Tollison, and Gordon Tullock. College Station, TX: Texas A \& M University Press.

Cleere, Henry. 1998. Europe's cultural heritage from a world perspective. In Sustaining the cultural heritage of Europe, ed. ICOMOS-UK. London, England: ICOMOS

—. 2006. Foreword. In Managing World Heritage Sites, ed. Anna Leask and Alan Fyall. London, England: Elsevier.

Cochrane, Janet, and Richard Tapper. 2006. Tourism's contribution to World Heritage Site management. In Managing World Heritage Sites, ed. Anna Leask and Alan Fyall. London, England: Elsevier.

Dreher, Axel. 2006. Does Globalization Affect Growth? Evidence from a new Index of Globalization. Applied Economics 38:1091-1110.

Dreher, Axel, Jan-Egbert Sturm, and James Raymond Vreeland. 2009. Development aid and international politics: Does membership on the UN Security Council influence World Bank decisions? Journal of Development Economics 88:1-18.

Frey, Bruno S. 1997. The Evaluation of Cultural Heritage. Some Critical Issues. In Economic Perspectives on Cultural Heritage, ed. Michael Hutter and Ilde Rizzo. London, England: Macmillan.

- 2003. Arts and Economics. Analysis and Cultural Policy. 2nd ed. Berlin, Heidelberg, Germany and New York, NY: Springer. 
Frey, Bruno S., and Paolo Pamini. 2009. Making World Heritage Truly Global: The Culture Certificate Scheme. Oxonomics 4:1-9.

2010. World Heritage: Where Are We? An Empirical Analysis. CESifo Working Paper Series 2919, CESifo Group Munich.

Frey, Bruno S., and Lasse Steiner. 2010. World Heritage List: Does it Make Sense? Working Paper Series ISSN 1424-0459, Institute for Empirical Research in Economics, University of Zurich.

Ginsburgh, Victor A. 2004. Economics of Art and Culture. Amsterdam, Netherlands: Elsevier.

Ginsburgh, Victor A., and David Throsby. 2006. Handbook of the Economics of Art and Culture. Amsterdam, Netherlands: Elsevier.

Greffe, Xavier. 1999. La gestion du patrimoine culturel. Paris, France: Anthropos.

Harrison, David, and Michael Hitchcock. 2005. The Politics of Heritage. Negotiating Tourism and Conservation. Channel View. Clevedon, England: Channel View Publications.

Henley, Jon. 2001. Fighting for the Mighty Monuments. The Guardian. August 6. http://www.guardian.co.uk/world/2001/aug/06/humanities.green (accessed August 1, 2010).

Howard, Peter. 2003. Heritage: Management, Interpretation, Identity. London, England: Continuum.

Hutter, Michael, and Ilde Rizzo. 1997. Economic Perspectives on Cultural Heritage. London, England: Macmillan.

Johnson, Peter, and Barry Thomas. 1995. Heritage as Business. In Heritage, Tourism and Society, ed. David T. Herbert. New York, NY: Mansell Publishing.

Klamer, Arjo, and David Throsby. 2000. Paying for the Past: the Economics of Cultural Heritage. In World Culture Report 2000; Cultural Diversity, Conflict and Pluralism (pp.130-145). Paris, France: UNESCO Publishing.

Leask, Anna, and Alan Fyall. 2001. World Heritage site designation: Future implications from a UK perspective. Tourism recreation research 26:55-63.

—. 2006. Managing World Heritage Sites, Amsterdam, Netherlands: Elsevier.

Leask, Anna, and Ian Yeoman. 2004. Heritage Visitor Attractions. London, England: Thompson Learning.

Li Fung, Sarah Mei, and Trevor H. B. Sofield. 2006. World Heritage Listing: the case of Huangshan (Yellow Mountain), China. In Managing World Heritage Sites, ed. Anna Leask and Alan Fyall. London, England: Elsevier. 
Maddison, Angus. 2007. Contours of the World Economy 1-2030 AD - Essays in MacroEconomic History. New York, NY: Oxford University Press Inc. See also Historical Statistics of the World Economy: 1-2008 AD, Copyright Angus Maddison, University of Groningen, http://www.ggdc.net/maddison (accessed on June 20, 2010).

Mason, Peter, and I-Ling Kuo. 2006. Visitor management at Stonehenge, UK. In Managing World Heritage Sites, ed. Anna Leask and Alan Fyall. London, England: Elsevier.

McKercher, Bob, and Hilary du Cros. 2001. Cultural Tourism: The Partnership between Tourism and Cultural Heritage Management, Binghampton, NY: Haworth Press.

Meskell, Lynn. 2002. Negative Heritage and Past Mastering in Archeology. Anthropological Quarterly 75:557-574.

Millar, Sue. 2006. Stakeholders and community participation. In Managing World Heritage Sites, ed. Anna Leask and Alan Fyall. London, England: Elsevier.

Mossetto, Gianfranco. 1994. The Economic Dilemma of Heritage Preservation. In Cultural Economics and Cultural Policies, ed. Alan Peacock and Ilde Rizzo. Dordrecht, Netherlands: Kluwer.

Mossetto, Gianfranco, and Marilena Vecco. 2001. Economia del patrimonio monumentale. Venice, Itlay: F. Angeli.

Musitelli, Jean. 2002. World Heritage, between Universalism and Globalization. International Journal of Cultural Property 11:323-336.

Netzer, Dick. 1998. International Aspects of Heritage Policies. In: Does the Past Have a Future? The Political Economy of Heritage, ed. Alan Peacock. London, England: Institute of Economic Affairs.

O'Brien, Patrick. 2007. Concise Atlas of World History. Concise edition. New York, NY: Oxford University Press.

Olmland, Atle. 1997. World Heritage - and the relationship between the global and the local. Master's thesis, Department of Archaeology, Emmanuel College, University of Cambridge. http://folk.uio.no/atleom/master/2.htm\#21 (accessed August 7, 2010).

Peacock, Alan. 1978. Preserving the past: an international economic dilemma. Journal of Cultural Economic, 2:1-11.

- 1995. A Future for the Past: The Political Economy of Heritage. Keynes Lecture in Economics. Proceedings of the British Academy, 87:189-243. Reprint in Cultural Economics: the Arts, Heritage and the Media Industries (pp. 1387-1424), ed. Ruth Towse. Aldershot, England: Edward Elgar, 1997.

1998. Does the Past Have a Future? The Political Economy of Heritage. London, England: Institute of Economic Affairs.

Peacock, Alan, and Ilde Rizzo. 2008. The Heritage Game. Economics, Politics, and Practice, Oxford, England: Oxford University Press. 
Polity. 2010. Polity IV Project: Political Regime Characteristics and Transitions, 1800-2009. Copyright by the Center for Systemic Peace, available at http://www.systemicpeace.org/polity/polity4.htm (accessed on June 20, 2010).

Pressouyre, Léon. 1996. The World Heritage Convention, twenty years later. Paris, France: UNESCO Publishing.

Regalado-Pezúa, Otto, and Jesús Arias-Valencia. 2006. Sustainable development in tourism: a proposition for Machupicchu, Peru. In Managing World Heritage Sites, ed. Anna Leask and Alan Fyall. London, England: Elsevier.

Rizzo, Ilde. 2006. Cultural Heritage: Economic Analysis and Public Policy. In Handbook of the Economics of Art and Culture, ed. Victor A. Ginsburgh and David Throsby. Amsterdam, Netherlands: Elsevier.

Rizzo, Ilde, and Ruth Towse. 2002. The Economics of Heritage. Cheltenham, England, and Northampton, MA: Edward Elgar.

Santagata, Walter, Stefano de Caro, and Massimo Marrelli. 2008. Patrimoni intangibili dell' umanità. Il distretto culturale del presepe Napolitano. Napoli, Italy: Guida Editore.

Shackley, Myra. 2006) Visitor Management: Case Studies from World Heritage Site. Oxford, England: Butterworth-Heinemann.

Strasser, Peter. 2002. "Putting Reform Into Action” - Thirty Years of the World Heritage Convention: How to Reform a Convention without Changing Its Regulations. International Journal of Cultural Property 11:215-266.

Streeten, Paul. 2006. Culture and Economic Development. In Handbook of the Economics of Art and Culture, ed. Victor A. Ginsburgh and David Throsby. Amsterdam, Netherlands: Elsevier.

Throsby, David. 1997a. Seven Questions in the Economics of Cultural Heritage. In Economic Perspectives on Cultural Heritage, ed. Michael Hutter and Ilde Rizzo. London, England: Macmillan.

_ 1997b. Sustainability and culture: some theoretical issues. International Journal of Cultural Policy 4:7-20.

—. 2001. Economics and Culture. Cambridge, England: Cambridge University Press.

—. 2003. Cultural sustainability. In A Handbook of Cultural Economics, ed. Ruth Towse. Cheltenham, England, and Northampton, MA: Edward Elgar.

_ 2010. The Economics of Cultural Policy. Cambridge, UK: Cambridge University Press.

Tisdell, Clement, and Clevo Wilson. 2002. World Heritage Listing of Australian Natural Sites: Tourism Stimulus and its Economic Value. Economic Analysis and Policy 32:2749.

Tollison, Robert D. 1982. Rent Seeking: A Survey. Kyklos 35:575-602. 
Towse, Ruth. 1997. Cultural economics: The arts, the heritage and the media industries.

Cheltenham, England: Edward Elgar.

(ed.) 2003. A Handbook of Cultural Economics. Cheltenham, UK, and Northampton, MA, USA: Edward Elgar.

_ 2010. A Textbook of Cultural Economics. Cambridge, UK: Cambridge University Press.

— and Mark Blaug. 1990. The Current State of the British Economics Profession. The Economic Journal 100 (399): 227-236.

Tunney, James. 2005. World Trade Law, Culture, Heritage and Tourism. Towards a Holistic Conceptual Approach. In The Politics of Heritage. Negotiating Tourism and Conservation, ed. David Harrison and Michael Hitchcock.. Clevedon, England: Channel View Publications.

UNESCO. 1972. Convention concerning the Protection of the World Cultural and Natural Heritage 1972, http://portal.unesco.org/en/ev.phpURL_ID=13055\&URL_DO=DO_TOPIC\&URL_SECTION=201.html (accessed August 7, 2010)

— 2005a. Operational Guidelines for the Implementation of the World Heritage Convention. http://whc.unesco.org/archive/opguide05-en.pdf (accessed August 7, 2010).

— 2005b. The Criteria for Selection, http://whc.unesco.org/en/criteria (accessed August 1, 2010).

- 2010. State Parties: Ratification Status. http://whc.unesco.org/en/statesparties/ (accessed on August 8, 2010).

van der Aa, Bart J.M. 2005. Preserving the Heritage of Humanity? Obtaining World Heritage Status and the Impacts of Listing. Amsterdam, Netherlands: Netherlands Organization for Scientific Research.

Wager, Jonathan. 1995. Developing a strategy for the Angkor World Heritage Site. Tourism Management 16:515-523.

Yang, Chih-Hai, Hui-Lin Lin, and Chia-Chun Han. 2009. Analysis of international tourist arrivals in China: The role of World Heritage Sites. Tourism Management 31:827-837. 